\title{
Absorptive Capacities of Local Enterprises from the Electric-Electronics Sector In the State of Tamaulipas, Mexico.
}

\author{
Francisco García Fernández', Mónica Sánchez Limón², José Ángel Sevilla Morales ${ }^{3}$
}

\begin{abstract}
The paper analyzes the absorptive capacities of a group of enterprises from the electric-electronics sector in the state of Tamaulipas Mexico. First, the literature on absorptive capabilities is reviewed, adopting an evolutionist approach. Then, an analysis of the sector is carried out in order to verify the recent changes made in various indicators - value of the total products by the selected states, job generation and productivity rates - based on data from the last three economic censuses. Finally, an analysis of the three selected enterprises' absorptive capacities is addressed from a case study perspective, making our own interpretation of the construct based on the integration of the different analyzed proposals.
\end{abstract}

Keywords: México; absorptive capacity; spillovers knowledge; technological capabilities.

1,2,3 Profesor de Tiempo Completo Facultad de Comercio y Administración Victoria Universidad Autónoma de Tamaulipas Email:ffernandez@uat.edu.mx,msanchel@uat.edu.mx, jasevilla@uat.edu.mx 


\section{Introduction}

There is agreement among scholars and business people that nowadays knowledge is the main strategic resource in organizations and that it plays an important role in securing their success and survival in the long run. Organizations can generate it or adopt it from external sources. However, both processes are complex and require that organizations devote financial and human resources to such activities. Knowledge, either produced or acquired, is now the only critical and decisive resource in organizations to build sustained competitive advantages (Nonaka, 2007).

Organizations generate deliberate socialization processes within themselves; they also design and implement knowledge management strategies with diverse aims (Bierly et. al., 2007; Donate Manzanares et. al., 2009), although they always attempt to obtain, as any other investment, the highest profit possible out of those assets.

Despite the high value attached to knowledge management by some organizations, especially the most successful ones, a part of it usually goes outside, deliberately or as revenue, through specific transfer mechanisms or informal channels. Different authors have stated that tacit knowledge is precisely the most volatile and difficult to protect; and therefore, the most complex and costly to copy and transfer to other organizations (Lundvall, 1992; Nonaka, 2007).

In order for organizations to be competitive, they need to permanently update their main resource: knowledge, to expand and keep their body of knowledge renewed. One way of doing so is through research and development activities which produce unique and relevant knowledge that is only available in few enterprises due to its high costs. Another way is by acquiring external knowledge, purchasing or copying it. They can also acquire it through other mechanisms such as the workers migration. Nowadays, most enterprises obtain a part of its knowledge from external sources due to the impossibility to internally generate all the knowledge needed. This in turn forces them to develop specific capabilities that enable them to adopt the knowledge generated in other contexts and under different routines and capabilities, and to incorporate it into their internal process of creating value, where organizational knowledge is transformed and absorbed.
The construction of absorptive capacity is not confined to the era of technological developments. However, it is clear that the acceleration in innovation processes and the reduction in innovations and knowledge life cycles since the 90's of the last century have created the need for organizations to make additional efforts to develop their own capabilities that enable them to absorb an important part of all the knowledge they cannot generate internally if they are to avoid becoming uncompetitive or being left at the technological borderline.

One of the sectors with the greatest competitiveness and accelerated technological change in the last decades is undoubtedly that of electrical-technological. It is a sector that has experienced a significant growth since the 1980's, as it has obtained greater growth rates than that of most of the developed countries' GNPs and the rest of the economy. In particular, this sector in Tamaulipas has also been able to expand in an accelerated way, making an important contribution to the increase in the value of the manufacturing product of the state. According to the last economic censuses (1999, 2004 and 2009), the contribution made by the sub-sectors 334 and 335 ranges from 10 to $15 \%$. However, this contribution is affected by different factors such as the high importance that the manufacturing product has in the state, and the sub-sectors involved in oil processing and the chemical industry which represent almost $70 \%$ of the 2009 census. Therefore, if we exclude the effect of those sub-sectors, the electrical-electronics sector substantially increases its participation up to $25 \%$ of the manufacturing value of the state, increasing to a $28 \%$ in the last census. This contribution is more in line with employment figures as it generates 67000 jobs in the state, according to official sources (INEGI, 2009).

The present paper intends to develop a deeper understanding of some of the effects that such an important sector as that of the electronics-electrical can have on enterprises within it. To this end, the absorptive capacity of a group of selected enterprises from the electronicselectrical sector of the Tamaulipas state was determined. First, the literature on absorptive capacity is reviewed, adopting an evolutionist approach. Then, an analysis of the sector is carried out in order to verify the recent changes made in various indicators - value of the total products by the selected states, job generation and productivity rates - based on data from the last three economic censuses. Finally, an analysis of the three selected enterprises' absorptive capacity is addressed from a case 
study perspective, making our own interpretation of the construct based on the integration of the different analyzed proposals.

\section{Analytical Framework.}

\section{I Knowledge, transference and spillovers.}

Multinational companies contribution to the technological development of industrializing countries has been a controversial phenomenon whose valuation has always depended on the authors' affiliation to one or another school of economic thought. Anyways the multinational companies and their essential tool, direct foreign investment, have been very important vehicles for technology transfer to the industrializing countries since World War II.

Hymer (1976) in one of his first research on the effects of foreign investment argued that direct foreign investment is not only a capital transfer, besides recipient countries also receive a combination of capital, business organization and new technology. Some authors distinguish the direct and indirect effects of multinational companies (Heijs, 2006). The first ones are associated with capital inflows, the modernizations of the productive system and the development of new sector. The indirect effects are harder to identify or quantify and deal with the impact of demonstration and imitation (espionage and learning), labor mobility and spinn offs, forward and backward linkages and access to new markets. Multinational companies direct effects are not the interest of this work although we are aware of the importance in promoting the technological developmet of countries of destination for foreign investment.

The indirect effects or externalities, main interest of this work, are associated to those effects or results that are obtained through the presence of multinational companies and that would not exist without them. This kind of effect is called technological or knowledge spillovers (spillover effects) because it responds primarily to spillover effects of foreign firms.

Authors such as Blomstrom and Kokko (2003) define technological spillovers as "the benefits that local companies gain from superior knowledge of technology related to the product, process or market of multinational companies, without incurring in a higher cost to those of the profits of increasing productivity".
To Escribano, Fosturi and Tribo (2005) knowledge spillovers are "involuntary knowledge flows that occur when part of the knowledge, generated by an organization, pours its boundaries and becomes available to other organizations". Marin (2008) argues that spillovers are "unintended benefits (even they are sometimes intentional) generated by multinationals in the host country, which are not entirely suitable for them". Instead, Dutrenit and Fuentes (2009) interpret them as "the benefits that local small and medium enterprises (SME) get from the superior knowledge flows of the global companies, which may be voluntary or involuntary by the global companies and allow performance improvements in SMEs.

There are at least three reasons that explain the existance of knowledge spillovers in developing countries (Marin \& Giulani, 2006; Blomstrom \& Kokko, 2003; Gorg \& Greenaway, 2004; Haskel et. al., 2002). The first one is related to the superiority often manifested that Multinational Companies have upon local companies, in terms of technological assets accumulated based on the innovation non-existent in the host country (Heijs, 2006). These assets give foreign companies, according to Chudnovky and López (1999), an advantage of property that can "derive from the possession of certain "intangible" assets (patents, trademarks, technology and management skills, ability to compete on product differentiation, etc. ) - often linked to the non-codified characteristic of technological knowledge and to the development of internal learning processes, and/or to the advantages that come up from the common governance of several but complementary activities, including those that are especifically derived from the multinationality of the company.

Other authors argue that knowledge is a type of public good within multinational companies, with great mobility and common to all the company and its subisidiaries (Marin \& Guiliani, 2006; Marin, 2008). These characteristics of knowledge makes it easily appropriated by the subsidiaries of the organization, which in many cases, implement socialization programs to be transferred to the subsidiaries, which are transformed in the origin of the knowledge spillovers to the local companies (Sánchez, 20II). Subsidiaries or for the particular case of Mexico can not prevent the escape of knowledge through multiple mechanisms to the local companies, mostly small and medium-sized, located in the direct environment. Despite the complexity of this process, knowledge spillovers are a positive phenomenon for the companies because of their 
low costs compared to the benefits they generate. And finally, the multinational company is a fully integrated organization, where the behavior of the subsidiaries depends on the centrally imposed strategies and decisions (Marin \& Guiliani, 2006).

According to this approach (Marin \& Guiliani, 2006) spillovers to local firms result from the combined effect of higher technology assets, ease of mobility intracompany knowledge and strong integration of the organization.

There are, according to several authors, many mechanisms or ways through which knowledge spillovers are generated by the multinational companies or their subsidiaries and transferred to local companies. These may be (i) through the movement of highly qualified workers; (ii) through the effects of demonstration and copying / imitating available technology in these companies; and (iii) through competition resulted from the pressure of the subsidiaries on local businesses, forcing them to improve and accelerate the processes of technology adoption, to streamline their own processes; (iv) links for suppliers which require local companies to produce inputs tobecome suppliers of the subisidiaries. This kind of link can lead to multinational companies train employees of local businesses that meet the requirements that they pose. In some cases, multinational companies may be interested in expanding the technological capabilities of local companies, making technology transfer activities so they can meet the required quality requirements (Görg \& Greenaway, 200I; Dutrenit \& Fuentes, 2009).

In this context is based the idea that everything that involves the transfer of knowledge, comes from the processes of accumulation of technological capabilities, absorptive capacity of local firms, where it should be stressed that such transfer occurs only when local firms benefit from the operation of multinational companies when they are linked together, since this allows them to create or maintain a competitive scheme in their productive and organizational processes.

\subsection{Absorptive capacity.}

Most of the companies need external knowledge either the one generated by research and development activities or the one that results from other companies, in specialized centers of science and technology development such as universities, public or private research centers. Nevertheless that external adoption process is complex. It does not occur automatically and without setbacks. In order to be able to incorporate that knowledge generated by external activities in their internal, companies need to develop a specific skill set that allow them to adapt it to the peculiarities of their companies.

Indeed the concept of absorptive capacity has been developed to highlight the importance of external sources of knowledge in the process of innovation and expansion of any company. Cohen and Levinthal $(1989,1990)$ were the first authors who presented a paper on the subject that reached a great spread and impact in the academic world. According to them, the absorptive capacity "the ability to recognize the value of new information, assimilate it and apply it for commercial purposes" (Cohen \& Levinthal, 1990).

For these authors, the most widely cited, absorptive capacity features the ability of companies to evaluate, assimilate, apply and profitably exploit the knowledge generated outside the organization. In the model of Cohen's and Levinthal (1990) absorptive capacity of organizations depends on the previous knowledge accumulated and emphasizes the investments in activities of Research and Development $(R+D)$ as the main knowledge-generating activity.

Subsequently, other authors developed the concept of absorptive capacity, but prioritized other sources of internal knowledge productions as alternatives to the importance given by Cohen and Levinthal (1990) to the R + D activities. Zahra and George (2002) reformulated the concept and suggested that it should be considered "as a set of organizational routines and processes by which firms acquire, assimilate, transform and exploit knowledge to produce organizational dynamic capabilities (p. 186)". The authors distinguished two kinds of absorptive capacity; potential and real. The first is associated with the capacity that firms have to acquire and assimilate external knowledge; the second has to do with their exploitation by the organization (Zahra \& George, 2002). 
Kim (1998) also made meaningful contributions to the development of the concept. For Kim (1998) the knowledge base is essential in the process of technological learning, making possible to assimilate new knowledge, to renew the current knowledge and increase the one of the future. This author emphasizes another determinant element of absorptive capacity, which is called intensity of effort. It refers to the amount of energy required by members of the organization to solve a problem. Indeed, to internalize an external knowledge requires effort and time, it is part of a learning process that goes from simple tasks or activities to other more complex that demand more direct effort.

Dutrenit and De Fuentes (2009) emphasize that the fundamental mechanism for the generation of absorptive capacity is the one derived from $R+D$ activities, however in the case of companies located in developing countries or in some traditional sectors, this can not be the most important source of generation and absorptive capacity neither the mechanism can be used as a key indicator mechanism. In these cases, the other two mechanisms related to the manufacturing operation of enterprises and direct investment through the training of workers play a crucial role in generating absorptive capacity.

Companies that have a high level of absorptive capacity tend to be proactive, exploit the available opportunities, look for new opportunities to develop their technological abilities and above all they are able to benefit more than their competitors from external knowledge and they also tend to establish stronger links with other local agents.

\subsection{Accumulated technological capabilities.}

Several scholars have contributed to shape the analytical framework of the concept of technological capabilities and the processes involved in building technological capabilities by firms in developing countries (Dutrenit et. al., 2003).

Westhpal, Kim and Dahlman (1985) define technological capability as "the ability to do an effective use of technological knowledge...; this is not in the knowledge you have but the use of knowledge and the ability to be used in production, investment and innovation". Belly and Pavitt (1995) refer to technological capabilities as the ones that generate and manage technology used in production; these capabilities are widely based on specialized resources". Kim (1997) defines technological capabilities as the abilities to use technological knowledge effectively in order to assimilate, use, adapt and change current technology. It also allows creating new technology and developing new products and processes to respond to the changing economic environment. Companies learn through time, accumulate technological knowledge, progressively undertake new activities and are able to acquire these new capabilities.

The basic idea is that capabilities are abilities and technological capabilities reflect domain on technological activities. From empirical work at the enterprise level, there have been created taxonomies that describe accumulation such as Dahlman and Westphal (1982), Lall (1992) and Bell and Pavitt (1995), from a stage that reflects basic levels of knowledge to the stage of advanced innovative capabilities (Dutrenit et. al., 2003; Torres, 2006).

Hobday and Rush (2007) have recently updated the analysis of industrial upgrading of technological capabilities in a study of the electronics industry in Thailand which was transformed into the main export sector of the country. Authors classified industrial upgrading in a "stage model", for which subsidiaries of multinational have been going through. This model consists of four stages: assembly; the basic stage is just a stage of an external supply chain; engineering process, a more complex level than simple assembly, incorporates a technical Department that performs improving and adaption tasks and finally Product Development and Research Development stage. These last two stages incorporate research, development or innovation activities what suggests advanced levels in building technological capabilities.

\subsection{Integrating the proposal.}

Absorptive capacity is an essential quality of any competitive company. The complexity and diversity of innovation processes, speed of technological change, requires companies to develop information systems to give guidance about what and where it is producing what they need and the state of competition in their environment and beyond. No company, however large, is able to produce all the knowledge necessary to the requirements of its current or future production processes. However companies forced to rely on external knowledge are the small medium-sized companies. Due to the scarcity and high costs of doing Research and Investigation activities, Small and Medium Enterprises are forced to deliberately develop absorptive capabilities in order to adapt that knowledge produced by others. 
In order to copy, companies need sophisticated knowledge systems, technological and learning capability to adapt and transform external knowledge in a consumable and usable input in their value creation activities. For Dosi (1988) knowledge bases in organizations are shaped by information, knowledge, and skills that companies need to be competitive, so the knowledge base is the result of a cumulative learning process. Kim (1999) takes up the proposal to Dosi and incorporates the ability to learn as part of the mechanism of adoption of external knowledge generated by the knowledge sources themselves. Therefore it is shared the view that learning ability is a basic element of the construction process of absorptive capacity of any company. Through these capabilities the organization adopts and transforms external knowledge to a large extent tacit, explicit knowledge and assimilated by the generation process of internal knowledge for their own work routines and in different productive activities and innovation of the company.
Therefore, we can assure that absorptive capacities are specific for every company and from the analyzed perspectives, they depend on the following elements: their current knowledge base, their accumulated technological capability, and learning capability (Cohen \& Levinthal, 1990; Kim, 1998).

Based on the above theoretical perspectives and the available information from the interviews with executives of the selected companies, we considered the measurement of the absorptive capacity from:

- The knowledge base (academic, experience and training).

- Accumulated technological capabilities (Quality certification, machinery and equipment and links with local agents).

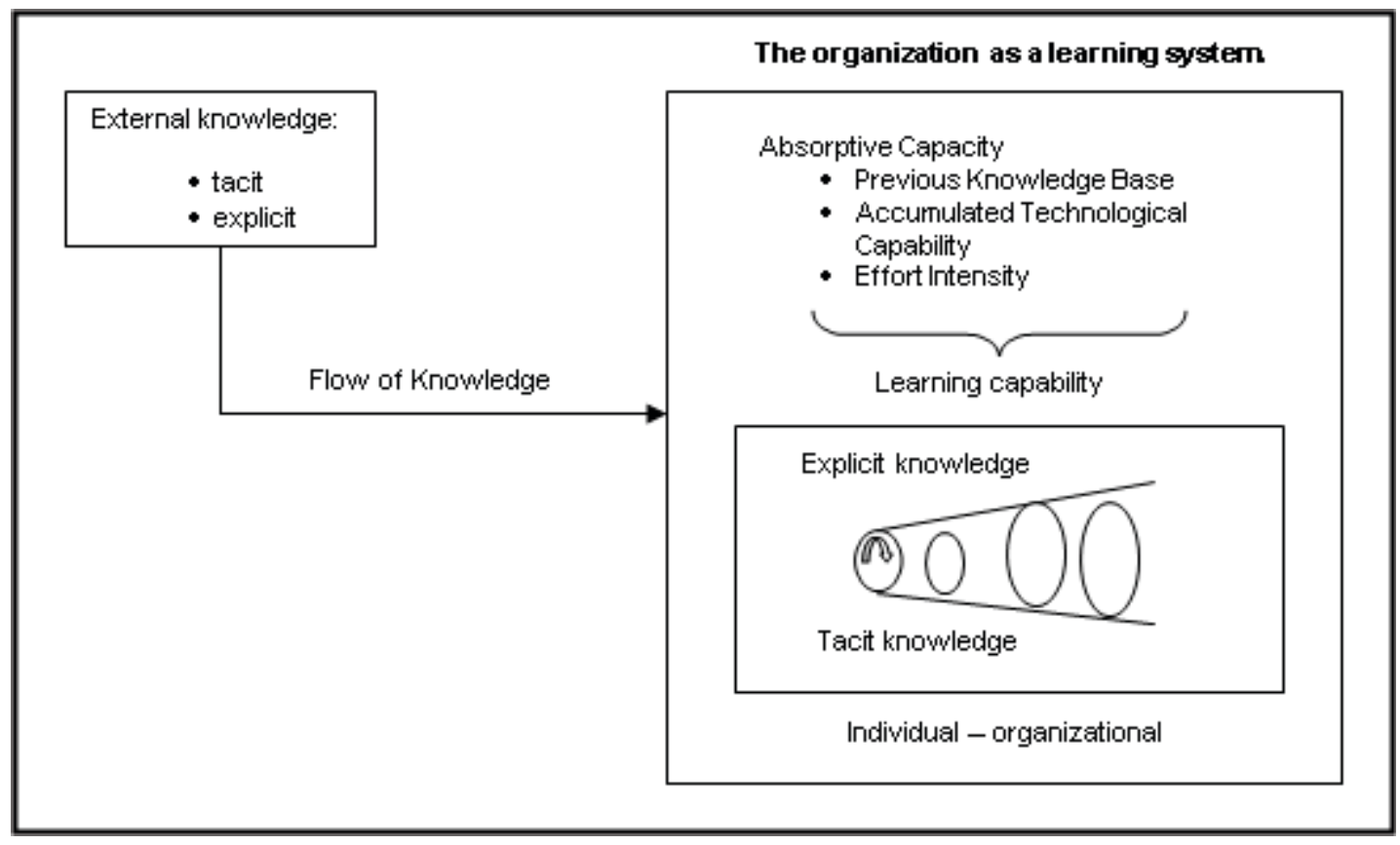

Source: Modified from Kim's model (1998). 


\section{The Electrical - Electronic Sector In The State Of Tamaulipas.}

The study coincides with a very special moment in the development of the industry in general and especially the factories (maquiladoras). Since late 2007 and early 2008 the U.S. economy underwent a crisis of great severity, called by some as the worst crisis in the U. S. economy after the Great Crash of 1929 to 1933 (Roubin \& Mihm, 2010; Bureau of Economic Analysis, 2009).

In this period, the manufacturing industry of the U.S. experimented a strong recessive tendency. From January 2008 to April 2009, the industry of that country fell $16.5 \%$, while the growth rate of manufacturing employment in that period in Mexico fell 9.4\% (INEGI, 20I0; Bureau of Economic Analysis, 20I0). The set of sub-sectors that make up the manufacturing industry in Mexico, also experienced sharp declines in their growth trends, with the exception of some industry oriented to the internal market such as the food industry. However within the industry in Mexico there were several declines depending on the degree of integration of the U.S. economy subsector. The five manufacturing subsectors with the largest negative growth rates of cumulative percentage between 2005 and April 2009 were: Transportation Equipment Manufacturing, Computer, Communication and Measurement Equipment Manufacturing, Electronic Components and accessories, furniture and related products, Manufacture of textile products, except apparel, manufacturing of textile inputs, manufacturing of wearing apparel (Tablel).

\begin{tabular}{|c|c|c|c|c|c|c|}
\hline Subsector/period & 2005 & 2006 & 2007 & 2008 & 2009 & $\begin{array}{l}\text { Acumulado } \\
2008-2009\end{array}$ \\
\hline Transportation Equipment Manufacturing & $5.64 \%$ & $4.38 \%$ & $0.09 \%$ & $-13.64 \%$ & $-6.77 \%$ & $-20.41 \%$ \\
\hline $\begin{array}{l}\text { Computer, communication, measurement } \\
\text { equipment manufacturing. } \\
\text { Manufacturing of electronic components. }\end{array}$ & $-0.54 \%$ & $-0.73 \%$ & $4.87 \%$ & $-7.84 \%$ & $-4.67 \%$ & $-12.52 \%$ \\
\hline $\begin{array}{l}\text { Furniture and related products } \\
\text { manufacturing }\end{array}$ & $3.78 \%$ & $1.50 \%$ & $-2.81 \%$ & $-8.90 \%$ & $-2.65 \%$ & $-11.55 \%$ \\
\hline $\begin{array}{l}\text { Manufacturing of textile products except } \\
\text { apparel. }\end{array}$ & $0.10 \%$ & $1.43 \%$ & $-4.20 \%$ & $-8.80 \%$ & $-0.99 \%$ & $-9.79 \%$ \\
\hline Manufacturing of textile input. & $-1.49 \%$ & $-1.74 \%$ & $-6.85 \%$ & $-7.92 \%$ & $-1.25 \%$ & $-9.17 \%$ \\
\hline Manufacturing of apparel. & $-3.92 \%$ & $0.55 \%$ & $-1.57 \%$ & $-7.22 \%$ & $-1.95 \%$ & $-9.16 \%$ \\
\hline
\end{tabular}

Table I. The five sub-sectors of manufacturing industry in Mexico with the largest declines in growth rate between 2005 and $2009 . /$ Source: Estimates using data from INEGI (20I0), monthly industrial survey (EIM) and Industrial Classification system of North America (NAICS).

The main sub-sector affected was transportation equipment, had a cumulative percentage contraction of $20.4 \%$. The second most affected country level is the sub-sector manufacture of computer, communication, measurement and other equipment, electronic components and accessories, whose production fell $12.5 \%$ in cumulative terms in the aforementioned period. This subsector showed effects of severe impasse as a result of the 200I crisis and the impact of Chinese exports to the U.S. market. Exports of electronic input and computer components also had the effect of reducing the demand from businesses and consumers in the U.S., as the expression of these sectors suffer stagnation since 2005 and from 2008 became frank decrease (Bureau of Economic Analysis, 2010). 
In particular, the 30 major sub-branches in the manufacture of Tamaulipas (considering their contribution to the state manufacturing GDP), contributing $84 \%$ of the value added of the industry, which are grouped mainly in four major sectors: automotive, chemical, petrochemical, electrical -electronic and textile industries. In fact, these four industrial complexes contribute about $70 \%$ of industrial GDP of the entity (INEGI, 20I0).

In Tamaulipas, the electric-electronic sector brings 20.2 percent of the value of manufacturing industry in the State, ranking second behind chemical - petrochemical that brings almost 30 percent (INEGI, 20I0). Both subsectors lead the dynamic of the industrial GDP due to its considerable involvement whole'.
Nationally, Tamaulipas is the fastest growing entity of electric-electronic sector, which is reflected in increasing its share in total production, from $4.44 \%$ to nearly $8 \%$ of the country (Figure I). Currently ranked sixth by the absolute value of the production sector, more than 21 000 million pesos and above the Distrito Federal.

On the level of employment, according to the 2009 economic census, the electricity sector employs 83.700 workers in the state, surpassing all other major sectors of the entity: automotive, chemical, petrochemical and textile industries. This represents $35 \%$ of all employment in manufacturing in the state. In addition, data from the census 2009 show an increase in employment by $50 \%$ compared with 2004, year of the previous census.

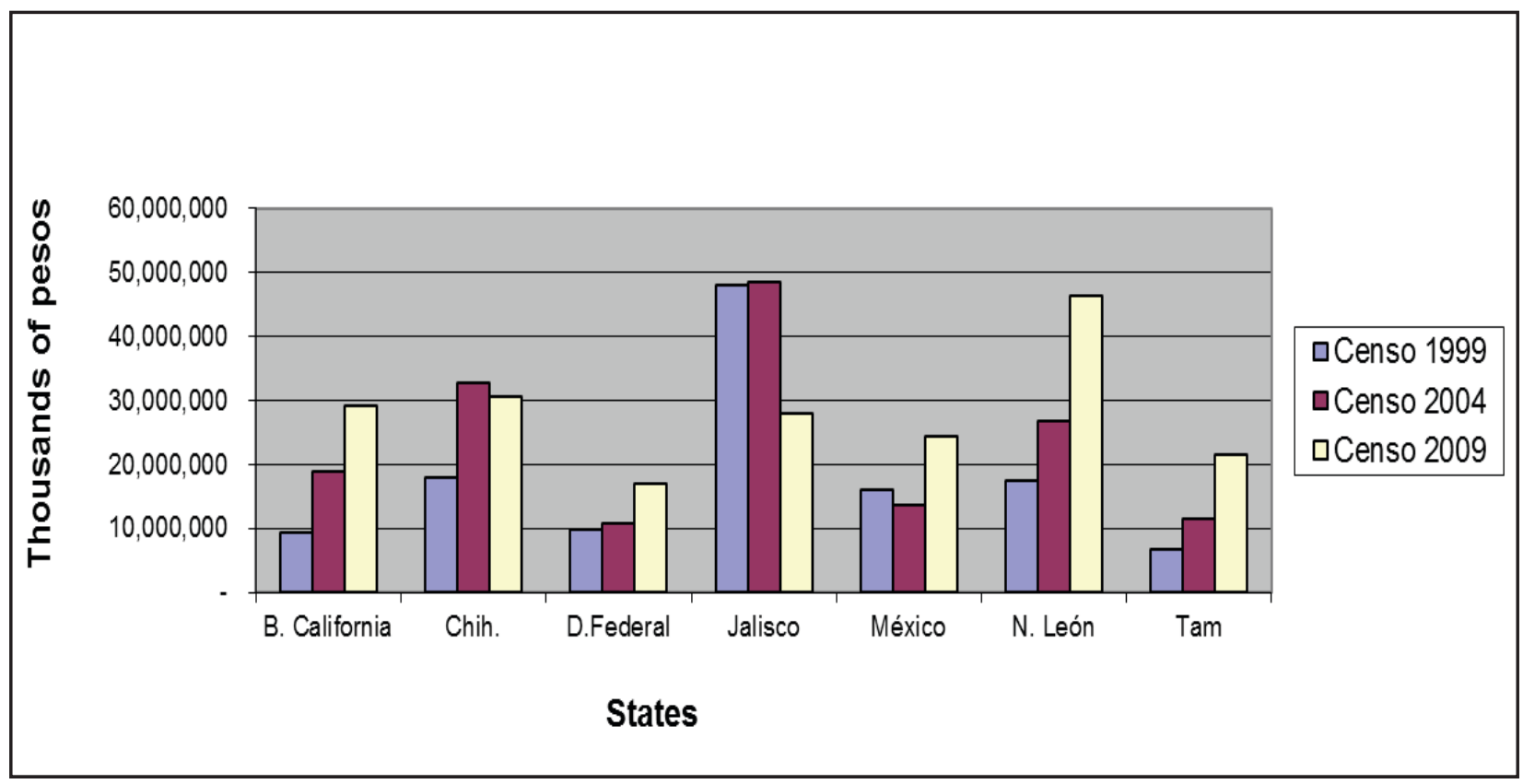

Figure 2: Gross total Electric-Electronic Sector in selected entities (million pesos)²/ Source: INEGI (I999, 2004, 2009).

\footnotetext{
' The study by Alvarez (2009) showed that all branches that make up the sub-sectors 334 and 335 in the state, except one, the generation equipment manufacturing and distribution of electricity, have a Blair concentration index greater than I, which means a concentration level of production higher than the national average.

${ }^{2} 21 \mathrm{t}$ has been considered the total value production in current pesos of the subsectors 334 (Manufacturing of computer equipment, communication, measurement and others, electronic components) and 335 (manufacturing of accessories, electrical devices and electric generation equipment).
} 
Compared to the other states of the country, in this sector (Figure 3), Tamaulipas ranks third in employment generation behind Chihuahua and Baja California. In 1999, the State was already third place and it has been like that since 2009 Census despite the reduction of the whole sector that shows 2004 Census and that was a result of the economic crisis of early decade of 2000 , phenomenon that impacted manufacturing industry in general (Figure 3).

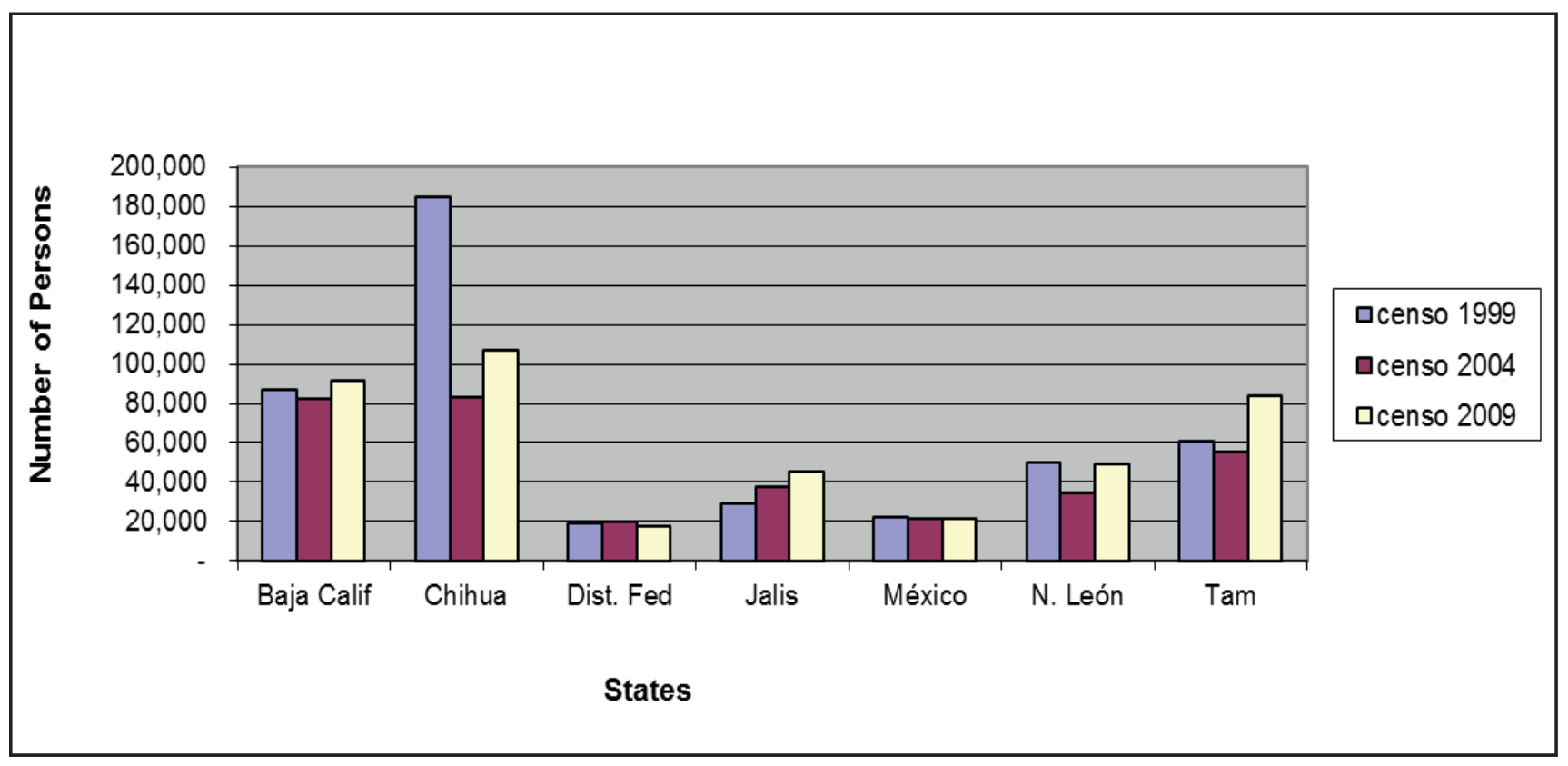

Figure 3: Employees in the Electric-Electronic Sector by State (Number of persons)./ Source: INEGI (I999, 2004, 2009).

In order to be able to determine the real situation of the sector, the labor productivity has been calculated. The results show that the labor productivity in the electricelectronics sector has not been able to increase as much as the employment and total production. The labor productivity has stayed still resulting Tamaulipas by the calculated labor productivity ranked the last place of the chosen States. As a result of the very low increase in productivity $-18.2 \%$ from yearly variation between 1999 and 2009- and below the growth that has been produced in the same period in the states of Distrito Federal, Estado de México, Baja California and Nuevo León (Figure 4).

This is also reflected in the incomes, resulting Tamaulipas one of the States with the lowest wages, compared to the other States that were studied (Economic Census from 1999, 2004, 2009). 


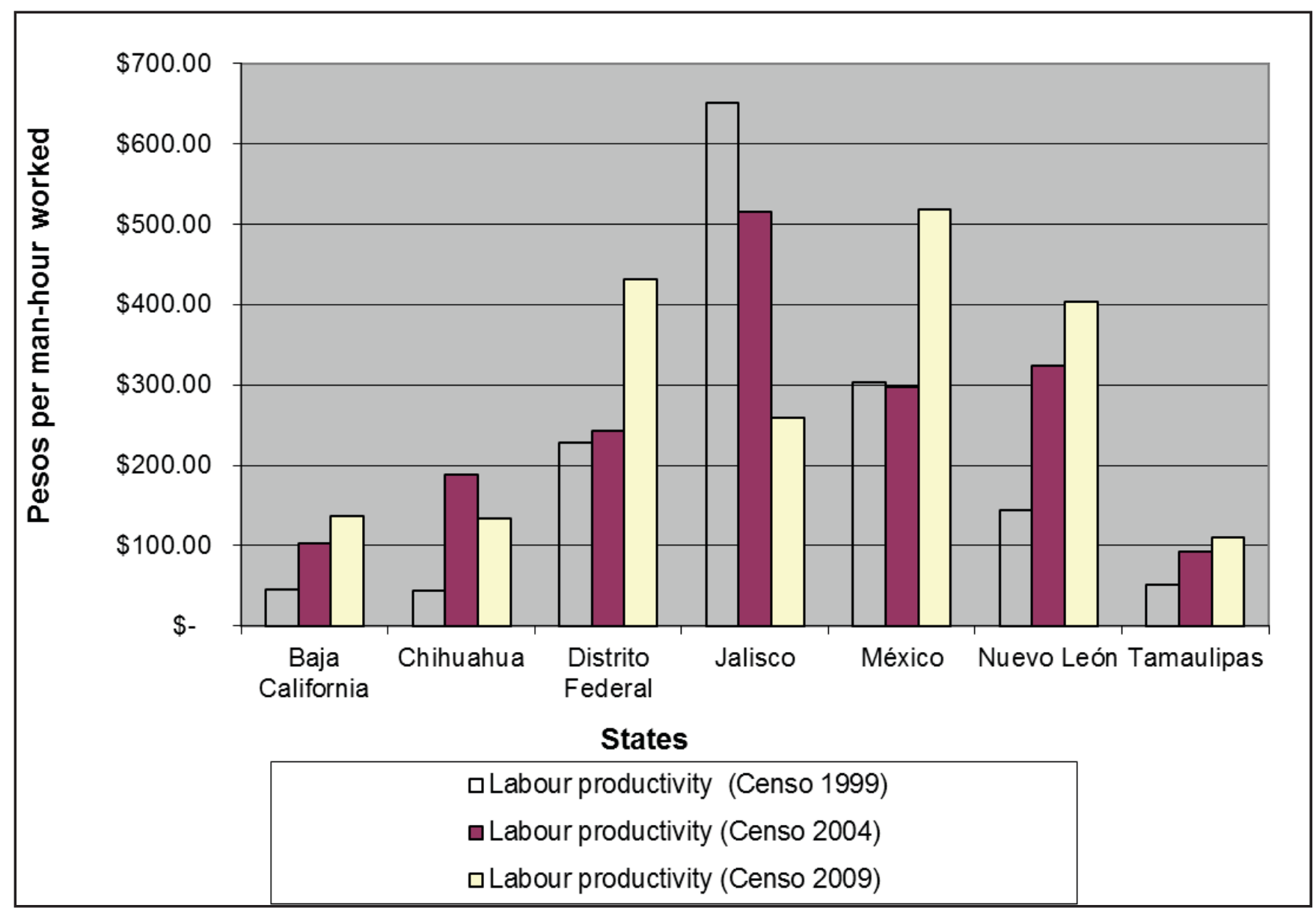

Figure 4: Labor productivity in the Electric-Electronics Sector, 1999, 2004, 200933 / Source: INEGI (I999, 2004, 2009).

\section{The Cases of Three Local Enterprises From The Electrical-Electronics Sector.}

In this section, three cases of local enterprises are presented. They are all medium-sized assembly plants from the electrical-electronics sector that have Mexican capital and work for the local market in the northeastern part of Mexico. The three enterprises are located in the state of Tamaulipas, two in Matamoros and one in $\mathrm{Cd}$. Victoria. In the first case (Highly Innovative), it is a local enterprise $(A)$ devoted to the production of electronics components of electrical household appliances with multiuse panels that has had an increase in the production volume as well as an important expansion in the market.
Their success is based on an aggressive strategy, which includes investment in training, technology, and customer satisfaction through the provision of a high quality service. It has an important capability of external knowledge acquisition, due to the fact that it owns a training and research center and has important liaison with local, state and federal organisms. The second case (B) Somewhat Innovative -, is a local enterprise that has been able to grow as a result of its efforts to expand its own productive capabilities, although it has not developed the same expansion levels as those of enterprise $A$. It is devoted to the production of electrolytic coverings and uses a costs savings strategy, which places emphasis on the acquisition of its own resources. It relies heavily on

\footnotetext{
${ }^{3}$ The labor productivity rate has been calculated based on the total number of worked hours in the sector, and taking the year of 1999 as the basis.
} 
the experience and skills of its engineers and specialists. Its absorptive Capacity is intermediate, as it makes limited innovation efforts. It has a technology strategy, which is oriented to the generation of specific knowledge related to green technology. This has influenced the development of its own knowledge body (professional training), which enables it to absorb an important portion of the external knowledge generated by its competitors. The third case (C), -Hardly Innovative-, is an enterprise, which focuses its efforts on the product; therefore, its strategy is based on employee training and the quality of its products. Its absorptive Capacity is rather low, although there is always room for the incorporation of explicit knowledge, which has been coded by its competitors and is available for its incorporation. However, there is no evidence in the collected data that suggests that it remains in the technological border, or that it is innovating to generate new technologies.

\begin{tabular}{|c|c|c|c|c|c|c|c|c|}
\hline $\begin{array}{c}\text { Enterpri } \\
\text { se }\end{array}$ & $\begin{array}{c}\text { Starting } \\
\text { date }\end{array}$ & Experience & $\begin{array}{c}\text { Origin of } \\
\text { capital }\end{array}$ & $\begin{array}{c}\text { Main products } \\
\text { line }\end{array}$ & $\begin{array}{c}\text { Technology } \\
\text { Strategy }\end{array}$ & S taff & Engineers & $\begin{array}{c}\% \\
\text { engineers }\end{array}$ \\
\hline A & 1997 & $\begin{array}{c}\text { More tan } \\
15 \text { years }\end{array}$ & MZxico & $\begin{array}{c}\text { Radius Chassis } \\
\text { Washers } \\
\text { components, } \\
\text { Dashboard } \\
\text { components }\end{array}$ & $\begin{array}{c}\text { Perfect } \\
\text { quality } \\
\text { based } \\
\text { systems }\end{array}$ & 240 & 15 & $36 \%$ \\
\hline B & 1996 & $\begin{array}{c}\text { Młs de 15 } \\
\text { a-0s }\end{array}$ & MŽxico & $\begin{array}{c}\text { Electrolytic } \\
\text { coverings }\end{array}$ & $\begin{array}{c}\text { Staff training } \\
\text { and } \\
\text { development } \\
\text { and the use } \\
\text { of green } \\
\text { technologies }\end{array}$ & 295 & 45 & $15 \%$ \\
\hline C & 1993 & $\begin{array}{c}\text { More than } \\
15 \text { years }\end{array}$ & MŽxico & $\begin{array}{c}\text { Electro- } \\
\text { mechanical, } \\
\text { civil and } \\
\text { hydraulic works } \\
\text { and high } \\
\text { quality } \\
\text { work }\end{array}$ & 90 & 9 & $10 \%$ \\
\hline
\end{tabular}

Table 2. Selected enterprises from the Electrical-Electronics Sector in Tamaulipas./ Source: Personal design.

\section{I Body Of Knowledge.}

The body of knowledge will be generated from the data collected by means of the interviews and questionnaires administered to the managers of the three Enterprises (A, B y C) selected for this study. The body of knowledge of an enterprise depends on various factors. In this case, following the theoretical perspectives discussed, we will take into consideration the academic background, the technical experience of the owner and the engineers, the training and the enterprises' certification. All these elements together should reveal the human resources' preparation available to meet the information and knowledge needs of the enterprise. The staff's academic background and the accumulated experience play important role in the implementation of any technological change at the enterprise level; they are also part of the organization capabilities and a source of the organizational and technical knowledge generation that an enterprise owns.

\section{Academic background and lifelong learning}

The owners and the managers of the three enterprises are bachelors' degree holders. In the Enterprises A and B, they also hold postgraduate degrees in business administration. In the Enterprise $C$, the chief executives are engineers and have at least two years of experience working in exportation assembly plants in the areas of maintenance, production, engineering and management.

After completing his studies in engineering the owner of $B$ started a workshop, which would supply small quantities of products to local companies. After that, he became a partner of another engineer from the city of Matamoros who had experience in assembly plants and founded together Enterprise B. Nowadays, they own three assembly plants which supply the local and the foreign market. 
The owners and/or managers of the analyzed enterprises have had previous experience working in assembly plants. Therefore, this has given them experience in the different areas that make up an assembly plant; and their knowledge can be transferred to these enterprises.

In the three analyzed enterprises, $80 \%$ of the labor is acquired locally and $20 \%$ in other states or abroad. $29 \%$ of the staff members (technicians and laborers) have higher education as their highest educational level, $38 \%$ hold high school diplomas, and $28 \%$ have junior high school education level. Only $5 \%$ of them have elementary school level.

\section{Technical Experience}

The analyzed enterprises agree that the technicians they hire must have at least four years of experience operating equipment and machinery. In the case of Enterprise A, they initially send the inexperienced technicians to the Corporate University where they develop the necessary experience to be able to operate the technology available at the Enterprise. In the case of the rest of the enterprises, their technicians have developed their experience either in other companies where they have previously worked or through their participation in training programs within the enterprise.

\section{Quality certification}

Among the main certifications that the analyzed enterprises are required to have are: ISO 900I:2008, ISO TS 16949, ISO QS 9000 . This indicates that the quality of these enterprises is related to a highly reliable production, which meets the high quality standards demanded by their customers. However, of the analyzed enterprises, one (C) is still in process of certification, with an $80 \%$ of progress.

These certifications indicate that such enterprises can guarantee quality processes and influence their expansion positively. The interviewed owners/managers argue that these certifications enhance the enterprise's credibility and that their customers trust the product quality even further.

\section{Training}

Regarding staff training, what Figueiredo (2002) considers an external knowledge acquisition mechanism, $100 \%$ of the participating enterprises from the local industry consider it essential and have internal and external sources of provision. A, for example, has a system called Corporate University which provides training to the staff members for four years. Through this system they gain experience and knowledge and have opportunities for promotions within the organizational structure.

$68 \%$ of the staff members required additional training for the operation of the companies' machinery. This is due to the fact that Enterprises A and B own highly specialized machinery with numerical and robotic control. The operation of such machinery requires further training. The rest of the staff members (32\%) did not require additional training, as they just operate basic and traditional technology.

\subsection{Accumulated Tecnological Capabilities}

\section{Machinery and equipment}

As for the machinery and equipment used in the analyzed enterprises, most of them use specialized machines. Enterprises (A) and (B) are equipped with numerical and robotics control machines. Enterprise $(A)$ leads in this respect due to its robotics technology and the experience that its technicians and engineers have developed through different sources of socialization. It is considered one of the local enterprises with the highest potential for development and liaison with foreign enterprises. Enterprise $\mathrm{C}$ owns specialized machinery and technology that runs on diesel.

\section{Liaison/network with local agents}

The relationships with other agents can be a source for knowledge transfer in various directions. These have the possibility to develop knowledge capable of being transferred and/or establishing networks with other institutions (HEl, EMN subsidiaries or headquarters, national industry, suppliers, customers) as they generate scientific and technological knowledge and they increase the number of specialized human resources available to the productive sector and society in general (Tamaulipas Government, 2008).

The enterprises under study have scarce relationships with educational institutions. Enterprise $C$ has signed agreements (formal relationships) with certain institutions for specific purposes such as social service, professional practice, and/or internships. Enterprises $A$ and $B$ have a second type of liaison (of formal nature as well), which allows the students of educational institutions that participate in social service or professional practice 
activities in such enterprises to be hired there. The purpose of this type of agreement is to offer the students opportunities for professional development, including the development of management and technological skills. Therefore, one outstanding aspect of the analyzed enterprises is that they have been able to accumulate technological capabilities based on the liaison they have established with educational institutions by means of their contribution to develop human resources.

\section{Liaison with local or foreign enterprises}

In this section, the liaison between the three local enterprises from the electrical-electronics sector and others from the same or other sectors is analyzed. Specifically, the liaison aimed at fostering the development of absorptive capacities of the local industry or at serving as a knowledge transfer mechanism is analyzed.

This type of liaison does not exist in Enterprise C, where such a relationship does not exist with other enterprises (except for that related to customers and suppliers). In the case of $B$, it maintains relationship with other analyzed enterprises from the electrical-electronics, establishing subcontracting processes for the assembly of the intermediate products they design. Enterprise A, unlike $B$, establishes relationship with local enterprises in order to form technological alliances. Some examples of this relationship are the cooperation with GW Industries - Metals Division, which is devoted to assembling the armor of air bags, the collaboration with Contract Manufacturing located in Brownsville, Texas, since 1994, which manufactures automotive small parts and high speed components and GM Systems, which recently became partner of Mid-South Industries and Select International Corporation in order to expand business capabilities to apply plastic injection molding.

\section{Customers}

The interviewed managers stated that despite the fact that their customers are demanding, it is because of them that the enterprise maintains the level it represents. The managers also stated that sometimes the customers themselves even participate in the product design process and provide support for the development of the product they demand. Foreign customers are more demanding than local ones, as they demand the highest quality possible and even certifications if they are to participate with them.
The percentage of foreign customers of the local enterprises is $35 \%$, which represents a demanding market in terms of delivery times and quality certifications. This requires the local enterprises to maintain acceptable competitiveness levels. Also, this places the enterprises from the electrical and electronics sector as competitors with a considerable level. One of the surveyed enterprises refers local customers and for the other two, they are mixed. That is to say, the enterprise has both foreign and local customers. Among the requirements for becoming a formal supplier of foreign enterprises are certifications, cleanliness, facilities, organization, and the automated machinery available.

The researched enterprises appear to value the collaboration that their customers provide in the design of their products and processes. In particular, Enterprise A carries out such collaboration in its research center. B carries it out within its enterprise. The other enterprise does not engage in collaboration with its customers to design and develop its products; it just adjusts itself to the provided design.

It is important to highlight that the local enterprises are expected to meet very strict requirements such as if they are to become suppliers of foreign enterprises. Those requirements include certifications, highly qualified members of the staff so they can perform functions related to the design and development of their products, and machinery with state-of-the-art technology. All these requirements have caused these enterprises to engage in highly competitive schemes, as well as to establish collaborative alliances with other enterprises in order to attract foreign customers. (Vera-Cruz et. al., 2005).

\section{Suppliers}

Of all the suppliers of the three researched enterprises, $65 \%$ are foreigners, which offer lower costs and higher quality; $21 \%$ are local suppliers; the rest of them (14\%) are a combination of both local and foreign suppliers. In this analysis, the level of purchase of inputs from foreign suppliers is high, which implies a disadvantage for local suppliers. However, the assembly plants justify this by arguing that they obtain more accessible costs and better quality. The lower level of participation of local suppliers is justified by stating higher costs, although the quality is acceptable. 


\section{Conclusions.}

The absorptive capacity of the enterprises from the electric-electronics sector in the state is unequal; they range from those that are highly innovative $(A)$ to those with limited capability of external knowledge absorption. Results of research projects conducted in states such as Chihuahua, Coahuila, Nuevo León among others have shown that enterprises from different sectors have been able to develop innovation capabilities, including knowledge absorptive capacities (Dutrenit et. al., 200I; Lara et. al., 2003; Carrillo \& Lara, 2004). Research on the effects of foreign investment in developing countries has concluded that local enterprises play an active role in the revenue generation process due to their capability of absorbing knowledge generated by multinational enterprises (Marin \& Giuliani, 2006).

The sector has grown substantially in Tamaulipas, compared to other states that are leaders in the electric-electronics production. Nowadays, it represents $8 \%$ of the total production, out-passing states with a stronger tradition in the industry. An important fact is that this sector is the most important in terms of job generation in the entire state, and based on the data analysis, its grown throughout the last decade has been higher than that of any other sector from the rest of the analyzed states. However, by productivity levels, the state is still behind, which is probably due to its scarce implementation of technology improvement and the dominance of a low status type of jobs in the state.

The analyzed local enterprises from the electric-electronics sector in the state have a diverse capacity of cumulative absorptive. As a result of its own efforts, the enterprise $A$ has an acceptable body of knowledge that allows it to compete for quality knowledge in the market and to incorporate it through different ways. The most advanced ones are the technological learning processes it has developed. This has enabled it to improve its body of knowledge substantially, as well as its technological competitive capabilities.

The Enterprise B has made efforts in the implementation of technologies which is very close to the technology frontier, substantially improving its absorptive capacity based on a strong academic background and capability of its engineers. In the case of Enterprise $\mathrm{C}$, a substantial deficit is evident in relation to the other two analyzed enterprises. Its absorptive capacity is very limited which is due to the few efforts made to improve its body of knowledge and to its under-competitive technological capabilities.

\section{References}

ALVAREZ, M. (2009). La localización: estrategias diferenciadas en la industria textil. Person Custom Publishing, México.

BELL, M. \& PAVITT, K. (1995). The Development Of Technological Capabilities. In: Haque, I. U. (ed.), Trade, Technology and International Competitiveness. The World Bank, Washington.

BERG, M., JOHNSON, J B., \& LUNDVALL, B. A. (2004). Absorptive Capacity, Forms of Knowledge and Economic Development. Document de Travail 2, Centre National de la Recherché Scientifique, Universite de Nice. Sophia, Antipolis.

BIERLY, P., \& DALY, P. (2007). Alternative Knowledge Management Strategies, Competitive Environment, and Organizational Performance in Small Manufacturing Firms. Entrepreneurship Theory and Practice, 3I (4), 493-5I6.

BLOMSTROM, M., \& KOKKO, A. (2003). The Economics of Foreign Direct Investment Incentives. NBER Working Paper, No. 948.

CARRILLO, J., (2009). Desarrollando la región fronteriza México - EE.UU. Hacia una región próspera y segura: Empresas innovadoras y políticas para la innovación en la Frontera México - EE.UU. James A. Baker III Institute for Public Policy Rice University. Binational Research Paper.

CARRILLO, J., (2007). La industria maquiladora en México: ¿evolución o agotamiento? Revista Comercio Exterior, 57 (8), 668-68I.

CARRILLO, J. \& LARA, A. (2004). Nuevas capacidades de coordinación centralizada. Maquiladoras de cuarta generación en México. Estudios Sociológicos, XXII (3), 647-667.

CHUDNOVSKY, D., \& LÓPEZ, A. (1999). Las empresas multinacionales de América Latina. Características, evolución y perspectivas. http://www.fund-cenit.org.ar/descargas/lasempresas.pdf [Accessed July 26, 20II]

COHEN, W., \& LEVINTHAL, D. A. (1990). Absorptive capacity: A new perspective on learning and innovation. Administrative Science Quarterly, 35 (I), 128-I52. 
COHEN, W., \& LEVINTHAL, D. A. (1989). Innovation and learning: the two faces of R\&D. Economic Journal, 99 (September), 569-596.

CONTRERAS, O., \& MUNGUIA, L. F. (2007). Evolución de las maquiladoras en México. Política industrial y tecnológica en México. Región y Sociedad, XIX, 7I-87.

DAHLMAN, C., \& WESTPHAL, L. (1982). Technological Effort in Industrial Development. An Interpretative Survey of Recent Research. In Stewart, F. James, J. (eds.) The Economics of New Technology in Developing Countries. Frances Pinter, Londres.

DOSI, G., (1988). The Nature of de Innovative Process. In: Dosi G. et al. Technical Change and Economic Theory. Pinter Publisher, London, 221- 239.

DUTRENIT, G., (2009). Sistemas regionales de innovación: un espacio para el desarrollo de las pymes. El caso de la industria de maquinados industriales. UAM/Textual S.A., México.

DUTRENIT, G., \& DE FUENTES, C. (2009). Abordajes teóricos sobre derramas de conocimiento y capacidades de absorción. In Dutrenit, G. (ed.) Sistemas regionales de innovación: un espacio para el desarrollo de las PYMES. El caso de la industria de maquinados industriales, UAM/ Textual S.A. México, 33-54.

DUTRENIT, G., VERA-CRUZ, A., \& ARIAS, A. (2003). Diferencias en el Perfil de Acumulación de Capacidades Tecnológicas. El Trimestre Económico, 277, 109-165.

DUTRENIT, G., \& VERA-CRUZ, O. (200I). Aprendizaje, conocimiento y capacidades tecnológicas. Monografía del proyecto Aprendizaje tecnológico y escalamiento industrial: generación de capacidades de innovación en la industria maquiladora de México, COLEF/FLACSO/UAM.

ESCRIBANO, A., FOSFURI, A., \& TRIBO, J. (2005). Managing Knowledge Spillovers: The Impact of Absorptive Capacity on Innovation Performance. Working Paper, Departamento de Economía, Universidad Carlos III de Madrid.

GROSSMAN, G. E., \& HELPMAN, E. (199I). Innovation and Growth in the Global Economy. The MIT Press, Cambridge.
GÖRG, H., \& GREENAWAY, D. (2004). Much Ado About Nothing? Do Domestic Firms Really Benefit from Foreign Investment? World Bank Research Observer, 19 (2), I7I-I97.

HASKEL, J., PEREIRA, S., \& SLAUGHTER, M. (2002). Does inward foreign direct investment boost the productivity of domestic firms? NBER Working Paper, 8724.

HYMER, S. (1976). The International Operations of National Firms: A Study of Direct Foreign Investment. MIT Press, Cambridge.

HEIJS, J. (2006). El papel de las empresas extranjeras en el desarrollo tecnológico de las economías nacionales. Revista Información Comercial Española, 830, 31-54.

HOBDAY, M., Rush, H. (2007). Upgrading the technological capabilities of foreign transnational subsidiaries in developing countries: the case of electronic in Thailand. Research Policy, 36(9), I335-1356.

INEGI -Instituto Nacional de Estadística y Geografía- (20I0). Encuesta Industrial Mensual: ampliada. INEGI, México.

INEGI -Instituto Nacional de Estadística y Geografía(1999, 2004, 2009). Censos Económicos. INEGI, México.

KIM, L., (1999). Building Technological Capability Industrialization: Analytical Frameworks and Korea's experience. Oxford University Press, Oxford

KIM, L., (1998). Crisis Construction and Organizational Learning: Capability Building in Catching-up at Hyundai Motor. Organization Science, 9 (4), 506-52I.

LALL, S., (1992). Technological Capabilities and Industrialization. World Development, 20 (2), 165-186.

LARA, A., TRUJANO, G., \& GARCÍA, A. (2003). Producción modular y escalamiento tecnológico en la industria automotriz: Un estudio de caso. UAM-Xochimilco, México.

LUNDVALL, B. Å., (1992). National Systems of Innovation: Towards a Theory of Innovation and Interactive Learning. Pinter Publishers, London. 
MARIN, A., (2008). Thinking locally: A subsidiary centred model of FDI - related Spillovers. http://smartech.gatech. edu/bitstream/handle//853/35670/anabel_marin_thinking_locally.pdf;jsessionid $=\mathrm{e} 0715 \mathrm{bc} 8 \mathrm{~b} 610 \mathrm{c} 26 \mathrm{be} 488870 \mathrm{~b} 3$ cle46f3.smart2?sequence $=1$ [Accessed January 16, 20II]

MARIN, A., \& GIULIANI, E., (2008). Relating global and local knowledge linkages: the case of MNC subsidiaries in Argentina. http://www.inter-net.it/aisre/minisito_2006/ cd_aisre/paper/marin.pdf [Accessed August 10, 20II]

MARIN, A., GIULIANI, E. (2006). Global and local knowledge linkages: the case of MNE subsidiaries in Argentina. SPRU Electronic, Working Paper Series Paper, 155.

MAEHLER, M. E., MARQUES, C.M., PEDROZO, E.A., \& PIRES, J. P. (20II). Knowledge Transfer and Innovation in Brazilian Multinational Companies. Journal Technology Management \& Innovation, 6 (4), I-I4.

NONAKA, I. (2007). The Knowledge-Creating Company. Harvard Business Review, July-August, 2-9.

PEREZ, C., (1986). Structural Change and Assimilation of the New Technologies in the Economic and Social System. In Freeman Ch (ed) Design, Innovation and Long Cycles in Economic Development, Frances Pinter, London,

PEREZ, C., (1990). Microelectronics Long Waves and World Structural Change: New Perspectives for Developing Countries. In: Freeman, Ch. (ed). The Economics of Innovation, Elgar Reference Collection, Edward Edgar, London, 464-486.

REICHERT, F.M., BELTRAME, R. S., CORSO, K. B., TREVISAN, M., \& ZAWISLAK. P. M. (20II). Technological Capability's Predictor Variables. Journal Technology Management \& Innovation, 6 (I), 14-25.

ROUBINI, N., MIHM, S. (2010). Cómo salimos de ésta. Destino, Madrid.

SANCHEZ, M., (2010). Acumulación, socialización y derramas tecnológicas de corporativos extranjeros en México. Pearson, México.

TORRES, A. (2006). Aprendizaje y construcción de capacidades tecnológicas. Journal Technology Management \& Innovation, I (II), 12-24.
VERA-CRUZ, A. O., DUTRENIT, G., \& GIL, J. L. (2005). Derramas de la maquila: el desarrollo de un sector de PYMES proveedoras, Revista Comercio Exterior, 55 (II), 92I-86.

WESTPHAL, L., KIM, I., \& DAHLMAN, C. J. (1985). Reflexions on the Republic of Korea's Acquisition of Technological Capability. In: Frischtak C and Rosenberg N (eds) International Technology Transfer: concepts, measures and comparisons. Praeger, New York: 167-221.

ZAHRA, S. A., \& GEORGE, G. (2002). Absorptive Capacity: A Review, Reconceptualization, and Extension. Academy of Management Review, 27 (2), 185-203. 